Article

\title{
Aggregate Removal Nanofiltration of Human Serum Albumin Solution Using Nanocellulose-Based Filter Paper
}

\author{
Lulu Wu, Athanasios Mantas $\mathbb{D}^{\mathbb{D}}$, Simon Gustafsson ${ }^{\mathbb{D}}$, Levon Manukyan ${ }^{\mathbb{D}}$ and \\ Albert Mihranyan *(D) \\ Nanotechnology and Functional Materials, Department of Materials Science and Engineering, Box 35, Uppsala \\ University, 75103 Uppsala, Sweden; lulu.wu@angstrom.uu.se (L.W.); athanasios.mantas@angstrom.uu.se (A.M.); \\ simon.j.gustafsson@gmail.com (S.G.); levon.manukyan@angstrom.uu.se (L.M.) \\ * Correspondence: albert.mihranyan@angstrom.uu.se
}

Received: 19 April 2020; Accepted: 10 July 2020; Published: 13 July 2020

check for updates

\begin{abstract}
This study is dedicated to the rapid removal of protein aggregates and viruses from plasma-derived human serum albumin (HSA) product to reduce the risk of viral contamination and increase biosafety. A two-step filtration approach was implemented to first remove HSA aggregates and then achieve high model virus clearance using a nanocellulose-based filter paper of different thicknesses, i.e., $11 \mu \mathrm{m}$ (prefilter) and $22 \mu \mathrm{m}$ (virus filter) at $\mathrm{pH} 7.4$ and room temperature. The pore size distribution of these filters was characterized by nitrogen gas sorption analysis. Dynamic light scattering (DLS) and size-exclusion high performance liquid chromatography (SE-HPLC) were performed to analyze the presence of HSA aggregates in process intermediates. The virus filter showed high clearance of a small-size model virus, i.e., $\log _{10}$ reduction value (LRV) $>5$, when operated at 3 and 5 bar, but a distinct decrease in LRV was detected at 1 bar, i.e., LRV 2.65-3.75. The throughput of HSA was also dependent on applied transmembrane pressure as was seen by Vmax values of $110 \pm 2.5 \mathrm{~L} \mathrm{~m}^{-2}$ and $63.6 \pm 5.8 \mathrm{~L} \mathrm{~m}^{-2}$ at 3 bar and 5 bar, respectively. Protein loss was low, i.e., recovery $>90 \%$. A distribution of pore sizes between $40 \mathrm{~nm}$ and $60 \mathrm{~nm}$, which was present in the prefilter and absent in the virus filter, played a crucial part in removing the HSA aggregates and minimizing the risk of virus filter fouling. The presented results enable the application of virus removal nanofiltration of HSA in bioprocessing as an alternative to virus inactivation methods based, e.g., on heat treatment.
\end{abstract}

Keywords: virus removal filtration; Cladophora cellulose; plasma-derived biologics; cell culture; cell therapies

\section{Introduction}

Human serum albumin (HSA) is one of the most important products derived from human plasma. It has a multifunctional role as an osmotic pressure regulator, transport shuttle and redox modulator [1]. HSA is used as an important component for producing drug-protein conjugates, e.g., for cancer treatment, due to its long blood circulation half-life [2] and accumulation in tumors [3]. HSA is also a critical supplement for cell culture media intended for cell therapies [4] and a widely used cryoprotectant for cells [5].

In recent years, there has been a sustained interest in developing recombinant HSA, which is commercially available in limited quantities for applications as (i) a cryoprotectant for other recombinant biologicals; (ii) a component in serum-free cell culture media for cell therapies; and (iii) a specialty component in diagnostic imaging agents [6]. The main challenges for recombinant HSA so far include the cost-efficiency of large-scale manufacturing and product purity $[7,8]$. 
Because most available HSA is still derived from human plasma, this infers the risk of virus contamination. Donor screening is the first step to mitigate the risk of viral contamination. The next step of assuring HSA's biosafety is pasteurization, which is typically performed at $60^{\circ} \mathrm{C}$ for $10 \mathrm{~h}$ in the presence of stabilizers, such as $\mathrm{N}$-acetyl tryptophan and/or caprylate (octanoate) [9]. Another stabilizer, i.e., $\mathrm{N}$-acetyl-L-methionine, was reported as an alternative to $\mathrm{N}$-acetyl-tryptophan as an HSA stabilizer $[10,11]$. The time of pasteurization is critical for efficient inactivation of virus particles, e.g., $4 \mathrm{~h}$ pasteurization may not be sufficient to inactivate hepatitis B viruses as opposed to a $10 \mathrm{~h}$ treatment [12]. While the method has been widely accepted in manufacturing of HSA in industry, the emergence of new viruses, e.g., Zika virus and Chikungunya virus, stipulates constant revalidation of the process [13-17]. Pasteurization of HSA $\left(60^{\circ} \mathrm{C}, 10 \mathrm{~h}\right)$ was shown to reduce the infectivity of most known human viruses including human parvovirus B19, hepatitis A virus, human immunodeficiency virus and West Nile virus [18-21], but it may be ineffective against animal parvoviruses, e.g., canine parvovirus (CPV) and minute virus of mice (MVM) [21]. The presence of N-acetyl-tryptophan or caprylate in HSA has little effect on inactivation kinetics during pasteurization, unlike other blood-derived products which may be stabilized by different excipients such as sucrose and $\mathrm{CaCl}_{2}$. [21]. However, the presence of high quantities of HSA stabilizers (e.g., typical stabilizer: Albumin molar ratio > 5:1) negatively affects the binding and transport properties of HSA, especially with respect to lipophilic molecules [22,23]. Further, pasteurized HSA does not have the redox properties of native HSA and contains higher quantities of cysteinylated, i.e., Cys34-bound, albumin, especially S-nitrosoalbumin [24]. Moreover, excessive amounts of stabilizers can lead to undesired biological side effects. For instance, both caprylate and $\mathrm{N}$-acetyl-tryptophan have been identified as vasodilators and may contribute to reduced renal perfusion [25]. Caprylate used as a stabilizer for HSA supplement was found detrimental for mesenchymal stem cell growth and differentiation [26]. In all, it would be advantageous to develop virus clearance processes that would eliminate the need for pasteurization and thereby remove the need for stabilizers.

Virus removal filtration is a well-established method of filtering biologicals thanks to its inertness and proven removal performance. However, virus removal filtration of HSA is rarely used due to cost-efficiency issues. Another technical challenge with HSA filtration is its tendency to form aggregates during pasteurization, which leads to rapid clogging of filters. It has been shown that when fatty acids are bound to HSA, its structure does not unfold upon heating even upon extended heating [27]. Since stabilizers dramatically increase structural stability of HSA upon heating, aggregate formation upon heating proceeds due to alternative pathways. In particular, it is believed to be associated with carry-over impurities, which are present in plasma-derived HSA, e.g., haptoglobin, transferrin, Gc-globulin and $\beta 2$-glycoprotein, and which unfold upon heating and thereby promote aggregate formation $[28,29]$. In this respect, it should be noted that even though clinical-grade HSA is considered to be pure $(\geq 95-96 \%)$, there are traces of as many as 141 different proteins other than HSA [30]. Chemical and immunochemical analysis of HSA aggregates from commercial vendors shows that these aggregates contain only $30-50 \%$ HSA, whereas the rest is made from denatured thermolabile proteins, i.e., mainly haptoglobin $[28,31,32]$. To confirm the deleterious effect of impurities, it was reported that affinity chromatographic (concanavalin A) removal of haptoglobin and hemopexin greatly reduces the aggregate formation tendency of pasteurized HSA [29]. Aggregate formation mainly proceeds through disulfide bonds between albumin and small amounts of denatured impurity globulins during the pasteurization step. It has earlier been reported that capping the free thiol group in bovine serum albumin (BSA) molecules with cysteine induces a remarkable decrease in the amount of the BSA aggregates during ultrafiltration [33]. Overall, aggregate products present in HSA negatively affect filterability of albumin.

In recent years a new type of virus removal filter paper has been developed at Uppsala University, which combines desirable pathogen removal properties with high cost-efficiency. Using naturally-sourced cellulose nanofibers, a nonwoven filter paper was produced via conventional hot-pressing of wet pulp [34]. The resultant paper featured a pore size mode of $19 \mathrm{~nm}$, which enabled 
removal of surrogate nanoparticles such as fluorescently-labeled latex nanobeads of varying size, and a real virus, i.e., swine influenza virus A [34]. The virus removal capability was further confirmed using large-size model viruses such as retroviruses (100 nm; enveloped), i.e., xenotropic murine leukemia virus $(x M u L V)$, with excellent clearance, i.e., $\log _{10}$ reduction value (LRV) $\geq 5.25$ [35]. The potential of using nanocellulose-based filter paper for viral clearance was ultimately confirmed for the worst-case small-size model viruses, i.e., parvoviruses (20 nm, nonenveloped) [36].

The produced filter paper consists of numerous stacked nanosheets formed via self-assembly of cellulose nanofibers during drainage, wet-cake formation and then hot-press drying, giving rise to -called mille-feuille structure [36]. By controlling the evaporation rate of moisture, the pore size mode can be varied between 10 and $25 \mathrm{~nm}$ [37]. The latter means that it is possible to remove particles of a certain size in solution by controlling the pore size distribution of the nanocellulose-based filter paper, something that will be explored in this manuscript.

Possible applications of mille-feuille filter paper in downstream and upstream bioprocessing purification have been studied. For upstream bioprocessing, filtration of virus spiked basal media, e.g., Dulbecco's modified Eagle's medium (DMEM), LRV $\geq 5$ was shown for small-size $\Phi$ X174 phages [38]. The filters were also found useful for filtering chemically-defined Chinese hamster ovary (CHO) cells medium supplemented with insulin-transferrin-selenium (ITS) and containing Pluronic F-68 [39]. In addition to high virus retention capacity and good flow rates, the results also showed no impact on cell viability, morphology and confluence [39]. When applied in downstream bioprocessing, the filter exhibited 5-6 LRV of $\Phi$ X174 (28 nm) or MS2 (27 nm) phages during the filtration of spiked human plasma-derived intravenous immunoglobulin (IVIG) at 3 bar [40]. Recently, the filtration of plasma-derived human coagulation factor IX-rich prothrombin complex with mille-feuille filter paper was shown [41].

In this article the virus removal properties for filtration of plasma-derived HSA are explored. We present a two-step sequential filtration of HSA solution through nanocellulose filters of different thicknesses, i.e., first $11 \mu \mathrm{m}$ (prefilter) and then $22 \mu \mathrm{m}$ (virus removal filter), which enable size-exclusion based removal of undesirable protein aggregates and achieve high protein throughput as well as high virus clearance. The filters were made of identical material and showed only slightly different pore size distributions.

\section{Materials and Methods}

\subsection{Materials}

Human serum albumin (HSA) (200 mg mL $\mathrm{mL}^{-1} ; \geq 96 \%$ albumin) was purchased from a local apothecary store and contained the following excipients: sodium chloride, N-acetyl-tryptophan and caprylic acid. Phosphate buffer saline (PBS) was purchased from Sigma-Aldrich (Saint Louis, MO, USA). Total protein biuret reagent and sodium chloride were obtained from Sigma-Aldrich (Saint Louis, MO, USA). Escherichia coli bacteriophage $\Phi X 174$ (ATCC ${ }^{\circledR}$ 13706) and Escherichia coli (Migula) Castellani and Chalmers (E. coli) (ATCC ${ }^{\circledR}$ 13706-B1) were obtained from American Type Culture Collection (ATCC, Manassas, VA, USA). Yeast extract, tryptone and agar were obtained from Becton, Dickinson and Company (BD, Franklin Lakes, NJ, USA). Cellulose from Cladophora sp. algae, collected from Qingdao, China, was provided by Dr. Jun Liu, Jiangsu University.

\subsection{Methods}

Filter Paper Preparation

Cladophora cellulose raw material (0.2\% wt.) was predispersed in deionized water using an IKA T25 high-shear mixer (Staufen, Germany) prior to high pressure-homogenization. The final nanocellulose dispersion was prepared by passing the mixed cellulose suspension through a high-pressure LM20 
microfluidizer (Microfluidics, MA, USA). The dispersion was passed 3 times through a $200-\mu \mathrm{m}$ grid chamber and 1 time through a $100-\mu \mathrm{m}$ grid chamber under a pressure of $1800 \mathrm{bar}$.

The nanocellulose-based filters were prepared as previously described [39]. Briefly, the diluted dispersion was drained through a membrane $(0.65 \mu \mathrm{m}$ hydrophilic polyvinylidene difluoride

PVDF; Merck Millipore, MA, USA) using a vacuum filtration setup (Advantec, Dublin, CA, USA) until a cellulose cake was formed. The wet cake was then dried in a Carver 4122CE press (Carver, IN, USA). For the preparation of $11 \mu \mathrm{m}$ thick prefilters, the nanocellulose wet-cake was dried at $140{ }^{\circ} \mathrm{C}$ using a hot-press for $40 \mathrm{~min}$. For the preparation of the $22 \mu \mathrm{m}$ thick virus removal filter, the nanocellulose wet cake was dried at $80^{\circ} \mathrm{C}$ using a hot-press for $24 \mathrm{~h}$. The dry filters were removed, cut into $47 \mathrm{~mm}$ diameter disc, and stored at ambient conditions until further use.

\subsection{Filtration}

\subsubsection{Filtration Setup}

An Advantec KST-47 (Advantec, Dublin, CA, USA) filter holder was used. A general-purpose filter paper disc $47 \mathrm{~mm}$ in diameter (Munktell, Eskilstuna, Sweden) was placed beneath the nanocellulose filter as a support. The rate of flow was monitored gravimetrically by collecting the outflowing liquid on an MS1602TS analytic balance (Mettler Toledo, Columbus, OH, USA) connected to LabX software (Version 2.5, Mettler Toledo, Switzerland).

\subsubsection{Prefiltration}

Eleven $\mu \mathrm{m}$ filters were used for prefiltration. Feed solution was $10 \mathrm{mg} \mathrm{mL}^{-1} \mathrm{HSA}$ diluted in PBS $(10 \mathrm{mM})$ adjusted to $\mathrm{pH}$ 7.4. The filters were wetted with PBS prior to prefiltration. Prefiltrations were carried out at 1 bar. Due to rapid clogging, for each prefiltration around $25 \mathrm{~mL}$ was passed through each filter, corresponding to a $14.4 \mathrm{~L} \mathrm{~m}^{-2}$ load volume. The permeate fractions were collected, mixed together and stored at $4{ }^{\circ} \mathrm{C}$ before use.

\subsubsection{Virus Removal Filtration}

ФX174 bacteriophage $(28 \mathrm{~nm})$ was used as a model small-size virus. Twenty-two $\mu \mathrm{m}$ filters were used for virus removal studies. A stock solution of $\Phi$ X174 was spiked at $0.1 \%$ into prefiltered $10 \mathrm{mg} \mathrm{mL}^{-1} \mathrm{HSA}$ in PBS adjusted to $\mathrm{pH}$ 7.4. Virus stability was controlled by a hold sample taken from the prefiltered spiked feed solution. The filters were wetted with PBS prior to filtration. Filtrations were carried out at 3 different overhead pressures, i.e., 1, 3, and 5 bar. For each pressure, around $50 \mathrm{~mL}$ of the entire loaded feed solution was passed through the filters, corresponding to a $28.8 \mathrm{~L} \mathrm{~m}^{-2}$ load volume. The permeate was collected in two equal fractions. The average flux during filtration was recorded as described above. Permeate samples and hold samples were collected and stored at $4{ }^{\circ} \mathrm{C}$ before plaque forming units (PFU) assay. The virus removal efficiency was expressed in $\log _{10}$ reduction values (LRVs) as described below.

\subsubsection{Vmax Analysis}

To quantify the throughput of down-scale virus filtering, Vmax analysis was performed on the resulting flux curve. An intermediate fouling model was selected according to a procedure described in Badmington et al. [42]. Vmax was calculated from the slope of the linear fit associated with each flux data curve where take time (h) was set as the $x$-axis and the reciprocal of the relative flux $\left(\mathrm{L} \mathrm{m}^{-2} \mathrm{~h}^{-1}\right)$ as the $y$-axis for linear fitting. When the resulting slope is positive, the reciprocal of the slope is $\operatorname{Vmax}\left(\mathrm{L} \mathrm{m}^{-2}\right)$ [42].

\subsubsection{Scanning Electron Microscopy}

To obtain a neat cross-section, the filter was first immersed in liquid nitrogen then broken with tweezers. After being sputtered with Au/Pd prior (Polaron, Ashford, UK), the samples were observed 
by a high resolution FEG Zeiss 1550 SEM (ZEISS, Jena, Germany) system. The selected acceleration voltage was set between $1.5 \mathrm{kV}$ and $3 \mathrm{kV}$ and In Lens detector was used for imaging.

\subsubsection{Nitrogen Gas Sorption}

Prior to analysis, the samples were degassed for $8 \mathrm{~h}$ in a vacuum at $95{ }^{\circ} \mathrm{C}$. Nitrogen gas sorption was performed using an ASAP 2020 (Micromeritics, GA, USA) instrument. Pore size distribution profiles were obtained using the Barret-Joyner-Halenda (BJH) method [43], based on the desorption branch of the isotherm curve. Data analysis was done using the manufacturer's software (ASAP, Micromeritics, GA, USA). The performance of the instrument was validated using a porous standard, i.e., Micrometrics ${ }^{\mathrm{TM}}$ Silica-Alumina (SSA $210 \mathrm{~m}^{2} \mathrm{~g}^{-1}$; lot number: A-501-49). The deviation between the pore-size mode of the calibration data from the nominal standard values was $0 \mathrm{~nm}$. Measurement on experimental samples was performed in triplicate, and the results were averaged.

\subsubsection{Dynamic Light Scattering}

Dynamic light scattering (DLS) was used to assess the particle size distribution of $10 \mathrm{mg} \mathrm{mL}^{-1} \mathrm{HSA}$ in PBS solution (pH 7.4) with a Zetasizer Nano ZS DLS instrument (Malvern, Malvern, UK). The feed solution, prefiltrate and final permeate were used for analysis. The test angle was $173^{\circ}$ (backscatter). About $1.2 \mathrm{~mL}$ of the test sample was taken each time and equilibrated in a DLS instrument for $10 \mathrm{~min}$ at $25{ }^{\circ} \mathrm{C}$ before testing. Three parallel samples of each group were used for testing and the results were averaged.

\subsubsection{Size Exclusion High Performance Liquid Chromatography (SE-HPLC)}

An HPLC-UV system was used for size-exclusion chromatography. A Hitachi 5160 pump (Hitachi Chromaster, Tokyo, Japan) was used with a 5280 autosampler, and a bioZen $1.8 \mu \mathrm{m}$ SEC-3 analytical column Mw 10-1500 kDa (Phenomenex, Værløse, Denmark). The column temperature was $25^{\circ} \mathrm{C}$, and injection temperature was $20^{\circ} \mathrm{C}$. The mobile phase was $100 \mathrm{mM}$ sodium phosphate $\mathrm{pH} 6.8$. The flow

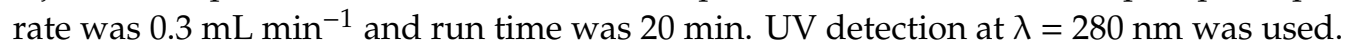

\subsubsection{Protein Recovery}

Total protein biuret reagent was used to assess protein recovery post filtration of HSA solutions. Six replicates were made for each sample; $50 \mu \mathrm{L}$ of sample was mixed with $150 \mu \mathrm{L}$ total protein reagent and the reaction was protected from light for 10 to $30 \mathrm{~min}$ then absorbance was measured at $540 \mathrm{~nm}$ using a Tecan M200 microplate reader. The recovery rate was calculated using Equation (1) as follows:

$$
\mathrm{R}=\frac{\mathrm{Abs}_{\text {permeate }}}{\mathrm{Abs}_{\text {feed }}} \times 100
$$

where $\mathrm{R}$ is the protein recovery in percent, $\mathrm{Abs}_{\text {permeate }}$ and $\mathrm{Abs}_{\text {feed }}$ are the absorbance values at $540 \mathrm{~nm}$ for permeate and feed, respectively. It was ascertained that the concentration-absorbance relationship was linear in the studied range of HSA concentration $\left(r^{2}=0.99968\right)$.

\subsubsection{Plaque Forming Units (PFU) and $\log 10$ Reduction Value (LRV)}

The titer of $\Phi$ X174 bacteriophage was determined by a plaque forming units (PFU) assay. The feed and permeate samples were serially diluted in Luria-Bertani medium (LBM) (1\% tryptone, $0.5 \%$ yeast extract, and $1 \% \mathrm{NaCl}$ in deionized water), and $100 \mu \mathrm{L}$ of diluted bacteriophage was mixed with $200 \mu \mathrm{L}$ of $E$. coli stock. The resulting suspension was mixed with $1 \mathrm{~mL}$ of melted soft agar and poured on 
the surface of a prepared hard agar plate $(55 \times 15 \mathrm{~mm})$ and incubated at $37^{\circ} \mathrm{C}$ for $5 \mathrm{~h}$. Bacteriophage titer was calculated using Equation (2):

$$
\log _{10}\left(\frac{\mathrm{PFU}}{\mathrm{mL}}\right)=\log _{10}\left(\frac{\text { average number of plaques }}{0.1 \cdot \text { dilution factor }}\right)
$$

where 0.1 is the volume $(\mathrm{mL})$ of added virus. The feed titer was adjusted to about $10^{5}$ to $10^{6}$ bacteriophages $\mathrm{mL}^{-1}$. The limit of detection, i.e., $\leq 0.7 \mathrm{PFU} \mathrm{mL} \mathrm{m}^{-1}$, of the current experimental design refers to $\leq 5$ bacteriophages $\mathrm{mL}^{-1}$, corresponding to a single detectable plaque in one of the plates for nondiluted duplicate samples, assuming that at the detection limit each plaque is produced by one bacteriophage. Virus retention was expressed as LRV ( $\log _{10}$ reduction value):

$$
\mathrm{LRV}=\log _{10}\left(\frac{\mathrm{PFU}_{\text {feed }}}{\mathrm{PFU}_{\text {permeate }}}\right)
$$

\section{Results and Discussion}

Figure 1 shows scanning electron microscope (SEM) images of the studied filters. Figure 1A displays the surface topography of the nanocellulose filter in which the cellulose nanofibers appear stacked and interconnected. It can be seen that many cellulose nanofibers are not completely dispersed and are arranged in a rope-like shape. The insert in Figure 1A shows the magnified structure of the rope-like structures, which appear to be caused by tight winding and tangling of cellulose nanofibers. Compared to the rest of the surface, wherein an open web-like structure is seen, the rope-like structures appear densely packed and do not feature pores. Figure 1B,C shows cross-section images of 11 and $22 \mu \mathrm{m}$ filters depicting the differences in thickness between the filters. The edges of the cross-section images feature rough fringes, which are most likely caused by the rope-like structures. The rope-like structures overall confer mechanical strength to the filter.

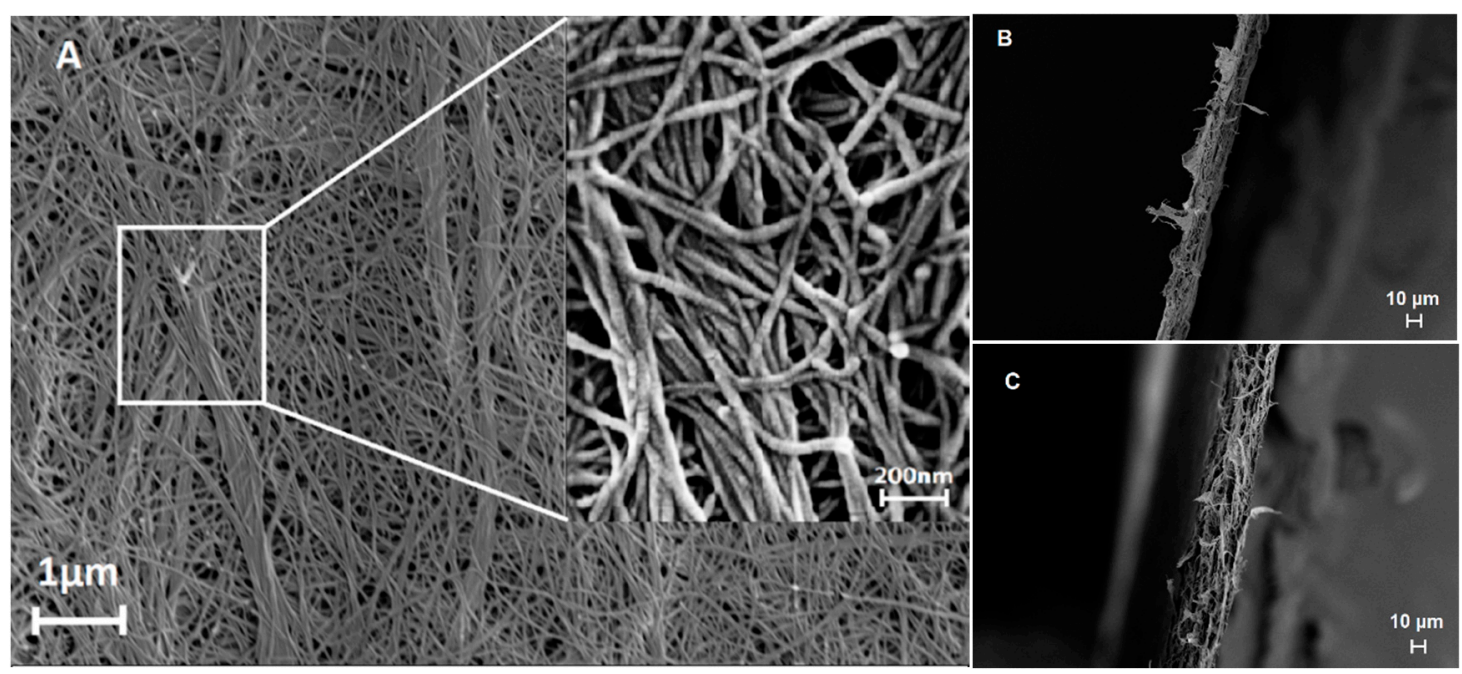

Figure 1. SEM images of prefilter $(11 \mu \mathrm{m})$ and virus filter $(22 \mu \mathrm{m})$ : (A) surface topography (B) cross-section of $11 \mu \mathrm{m}$ prefilter and (C) $22 \mu \mathrm{m}$ virus filter.

Figure 2 shows the results of the nitrogen gas sorption analysis. From the isotherm plot, shown in Figure 2A, it can be seen that both filters show a similar shape of the isotherm, featured with characteristic $\mathrm{H} 1$ hysteresis loops [44]. Figure 2B shows the BJH pore size distribution of the studied filters. It is seen from this graph that the filters feature different pore size distributions and pore volumes. The $11 \mu \mathrm{m}$ prefilter shows a broader size and larger pore volume than the $22 \mu \mathrm{m}$ filter. In particular, the pore size distribution of $11 \mu \mathrm{m}$ filters ranges from about $2 \mathrm{~nm}$ to about $80 \mathrm{~nm}$, whereas 
that of $22 \mu \mathrm{m}$ virus filter ranges between $2 \mathrm{~nm}$ to about $50 \mathrm{~nm}$ with a tiny pore fraction between 50 and $80 \mathrm{~nm}$. It is interesting to note that the main difference between the two filters comes from pores above $16 \mathrm{~nm}$, whilst in the region between 2 and $16 \mathrm{~nm}$ the difference between two filters is insignificant. The pore size mode of the $11 \mu \mathrm{m}$ filter is around $30 \mathrm{~nm}$, whereas that of the $22 \mu \mathrm{m}$ filter is around $20 \mathrm{~nm}$. The observed differences between the filters were caused by differences in the drying kinetics between the filters as shown previously by Gustafsson and Mihranyan [37]. The observed differences in the pore size distribution are key for performance of the filters as it will be evident from the discussion below.
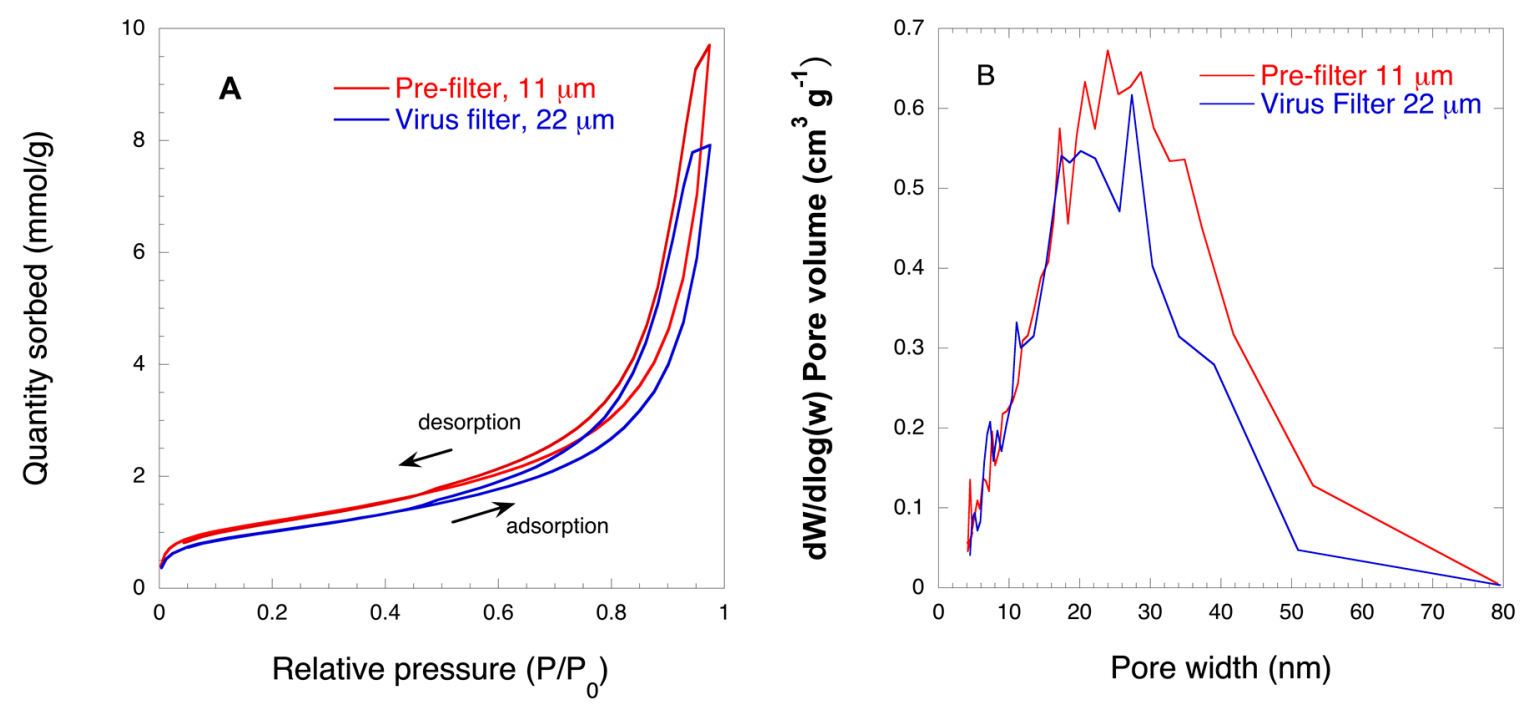

Figure 2. Typical nitrogen gas sorption isotherms (A) and average Barret-Joyner-Halenda (BJH) pore size distributions $(\mathrm{n}=3)(\mathbf{B})$ for $11 \mu \mathrm{m}$ prefilter and $22 \mu \mathrm{m}$ virus filter. Hysteresis loops of the nitrogen sorption isotherms were marked by an upward pointing arrow for adsorption and a downward pointing arrow for desorption.

Figure 3 shows the flux curves of the studied filters and Table 1 summarizes the protein recovery data. It is seen in Table 1 that the overall protein recovery was above $90 \%$. If the HSA solution was filtered without prefiltration, the filter was rapidly fouled and the flux dramatically decreased. On the other hand, if the solution was prefiltered through the $11 \mu \mathrm{m}$ filter, the protein throughput and flux properties were substantially improved when filtered through the $22 \mu \mathrm{m}$ filter. For prefiltration with the $11 \mu \mathrm{m}$ filter, when the permeate volume reached $5 \mathrm{~L} \mathrm{~m}^{-2}$ the flow rate quickly decreased from the initial $121.6 \mathrm{~L} \mathrm{~m}^{-2} \mathrm{~h}^{-1}$ to about $16.7 \mathrm{~L} \mathrm{~m}^{-2} \mathrm{~h}^{-1}$ and then slowly decreased to $6.7 \mathrm{~L} \mathrm{~m}^{-2} \mathrm{~h}^{-1}$. It should be noted that protein recovery after prefiltration was $94.3 \pm 1.5 \%$, suggesting that the fraction of protein causing fouling was relatively small. It should be noted that for practical applications in order to avoid rapid fouling of the prefilter and to maintain high throughput, the sizing of the prefilter can be adjusted, as is normally done in industry, given the high cost-efficiency of the prefilter. 


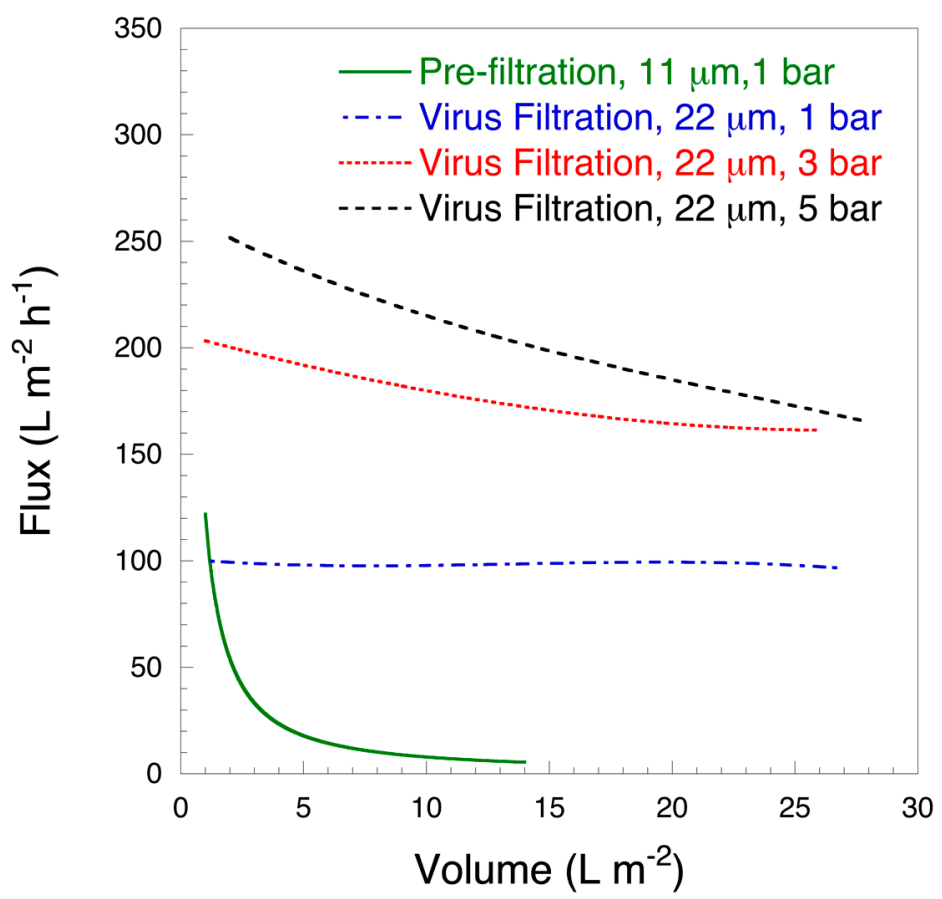

Figure 3. Representative flux curves for $10 \mathrm{mg} \mathrm{mL}^{-1} \mathrm{HSA}$ solution at $\mathrm{pH}$ 7.4. Feed volume $14.4 \mathrm{~L} \mathrm{~m}^{-2}$ (prefiltration) or $28.8 \mathrm{~L} \mathrm{~m}^{-2}$ (filtration) $(\mathrm{n}=3)$.

Table 1. Total protein biuret assay and Vmax calculated with intermediate fouling model $(n=3)$.

\begin{tabular}{cccc}
\hline Sample & Pressure, Bar & HSA Recovery, $\mathbf{~}$ & Vmax, $\mathbf{L ~ m ~}^{-\mathbf{2}}$ \\
\hline Prefiltration, $11 \mu \mathrm{m}$ & 1 & $94.3 \pm 1.5$ & $/$ \\
Virus filtration, $22 \mu \mathrm{m}$ & 1 & $90.7 \pm 6.6$ & $\geq 1000$ \\
Virus filtration, $22 \mu \mathrm{m}$ & 3 & $92.3 \pm 0.6$ & $110.0 \pm 2.5$ \\
Virus filtration, $22 \mu \mathrm{m}$ & 5 & $91.3 \pm 3.5$ & $63.6 \pm 5.8$ \\
\hline
\end{tabular}

For filtration with the $22 \mu \mathrm{m}$ filter, the flow rate varied depending on the applied overhead pressure. Under a constant pressure of 1 bar, the entire filtration flow rate was relatively stable at about $100 \mathrm{~L} \mathrm{~m}^{-2} \mathrm{~h}^{-1}$. After filtering at $28.8 \mathrm{~L} \mathrm{~m}^{-2}$, it only decreased to $96.7 \mathrm{~L} \mathrm{~m}^{-2} \mathrm{~h}^{-1}$ and the protein recovery rate was $90.7 \pm 6.6 \%$ from the feed HSA content, i.e., prior to prefiltration, calculated Vmax $\geq 1000$. Under a constant pressure of 3 bar, the filtration flow rate of $28.8 \mathrm{~L} \mathrm{~m}^{-2}$ slowly decreased from the initial $203.3 \mathrm{~L} \mathrm{~m}^{-2} \mathrm{~h}^{-1}$ to $161.7 \mathrm{~L} \mathrm{~m}^{-2} \mathrm{~h}^{-1}$ and the protein recovery rate was $92.3 \pm 0.6 \%$ with a calculated Vmax $110.0 \pm 2.5$. At a constant pressure of 5 bar, the flow rate slowly decreased from the initial $252.5 \mathrm{~L} \mathrm{~m}^{-2} \mathrm{~h}^{-1}$ to $165.8 \mathrm{~L} \mathrm{~m}^{-2} \mathrm{~h}^{-1}$, and the protein recovery was $91.3 \pm 3.5 \%$ with a calculated Vmax of $63.6 \pm 5.8$. The protein loss in the second filtration step was within the standard deviation range between the different groups and the main loss of about $5.6 \pm 1.5 \%$ occurred during prefiltration.

To understand the observed improvement in flow properties after two-step filtration, DLS and SE-HPLC analyses were performed, as discussed below. Figure 4 shows the intensity and volume distribution DLS profiles. It is seen from Figure 4A that the feed sample showed bimodal particle size distribution with peaks located at about 7.5 and $68 \mathrm{~nm}$, respectively. After prefiltration with the $11 \mu \mathrm{m}$ filter, the peak at around $68 \mathrm{~nm}$ could not be detected, whereas the intensity of the peak at $9 \mathrm{~nm}$ increased. It should be noted that the largest detected particle size was around $20 \mathrm{~nm}$ in the prefiltrate sample. No changes were observed after $22 \mu \mathrm{m}$ filtration compared to $11 \mu \mathrm{m}$ prefiltration as the distribution was monomodal. It is interesting to note that the volume distribution DLS profiles did not suggest the presence of significant number of larger particles in the feed. Nonetheless, there was a visible shift in the peak position to smaller size in the prefiltrate and permeate samples as compared to the feed sample. The latter suggests that the quantity of HSA aggregates in the feed 
solution was indeed low, but these aggregates, which arise during pasteurization [28,29,32], could still cause rapid filter fouling as was discussed in the Introduction section. Following filtration through the $11 \mu \mathrm{m}$ filter and then subsequently the $22 \mu \mathrm{m}$ filter, the peak shifted to smaller sizes. No differences were observed in the DLS distribution profiles of filtrates processed at 1, 3 and 5 bar.
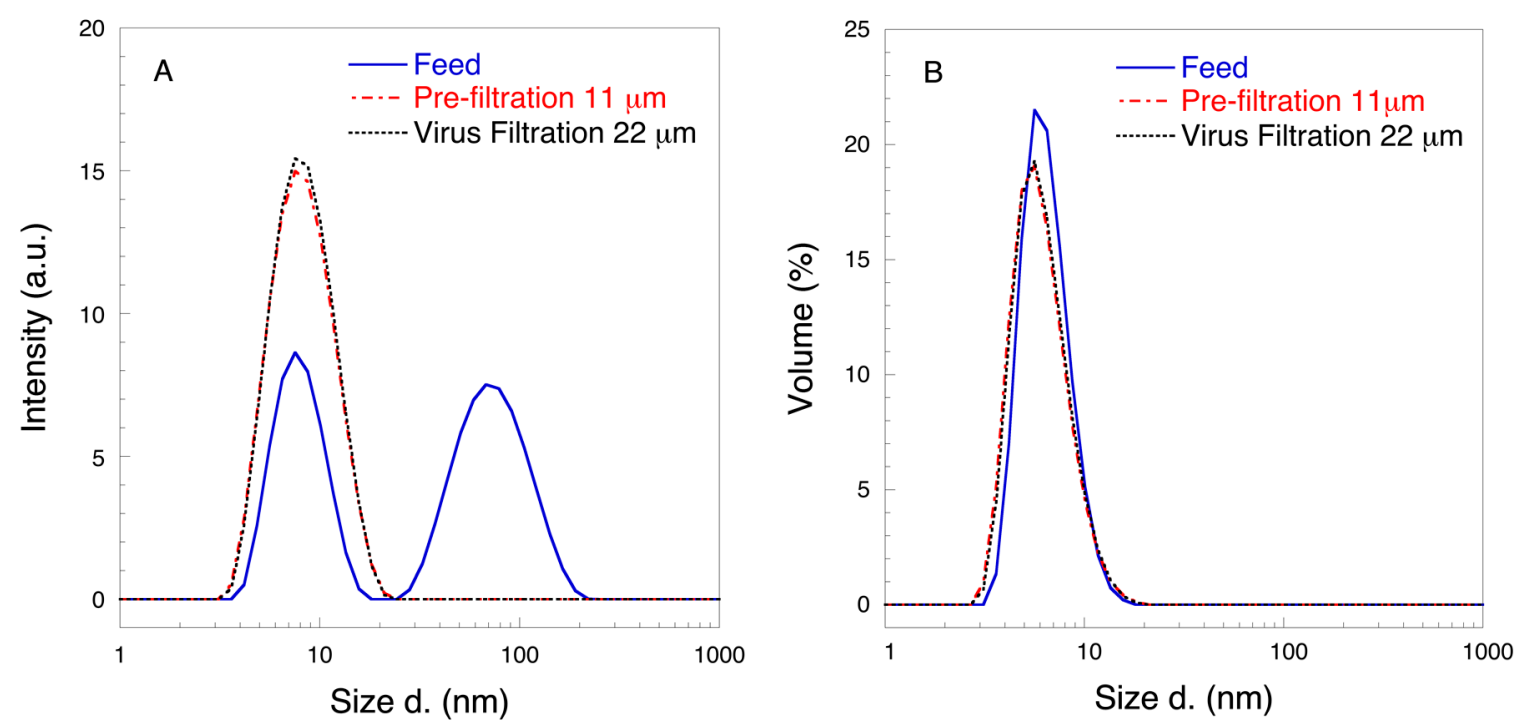

Figure 4. Representative dynamic light scattering (DLS) intensity (A) and volume (B) distributions of $10 \mathrm{mg} \mathrm{mL}^{-1} \mathrm{HSA}$ at $\mathrm{pH} 7.4(\mathrm{n}=3)$.

Figure 5 shows the SE-HPLC profiles of the studied samples. As it is seen in the graph, the feed sample featured two major and two minor peaks. The major peaks were HSA monomer and stabilizer whereas the minor peaks were HSA dimer and aggregates, respectively. After prefiltration, the aggregates were removed and HSA existed mainly as a monomer. No further changes were observed after filtration through the $22 \mu \mathrm{m}$ filter at any of the studied pressures. Furthermore, it was seen from the SE-HPLC profile that the intensity of the monomer peak did not significantly change after each respective filtration step compared to feed, which is concordant with the results of the total protein biuret assay in Table 1 and DLS volume distributions in Figure 4B. The results of SE-HPLC analysis were confirmed by ÄKTA-chromatography over Sephacryl-gel column, see Supplementary Materials, Figure S1.

To verify the virus clearance of the $22 \mu \mathrm{m}$ filter, HSA prefiltered solution was spiked with $\Phi$ X174 phage. Figure 6 shows the results of the virus clearance tests. At 1 bar constant pressure, an LRV $\leq 3.75$ was observed. As the load volume increased from $14.4 \mathrm{~L} \mathrm{~m}^{-2}$ to $28.8 \mathrm{~L} \mathrm{~m}^{-2}$, virus clearance decreased from $3.75 \mathrm{LRV}$ to $2.65 \mathrm{LRV}$ when operated at 1 bar. Furthermore, filtration at 1 bar was more time consuming than that at 3 or 5 bar. At 3 bar and 5 bar, constant pressure virus clearance was $>5$ LRV and stable for increasing load volume fractions. The results of Figure 6 suggest that a higher constant pressure during virus filtration is associated with better virus clearance and a faster flow rate with little effect on protein recovery. Better virus clearance at an overhead pressure $\geq 3$ bar is concordant with previously published data [34]. The observed improved clearance at higher pressure is related to a combined effect of compaction of the filter at higher pressure [45] and decreased tendency to Brownian motion [46]. 


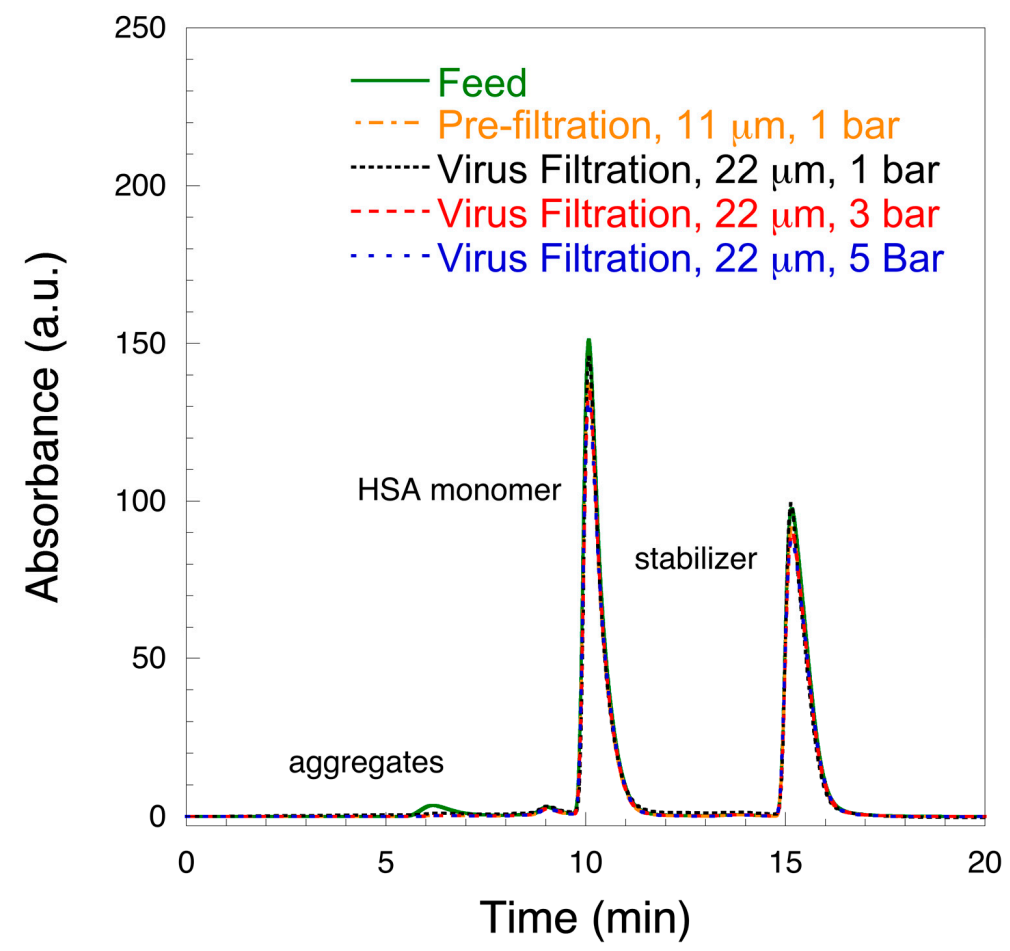

Figure 5. Size-exclusion high performance liquid chromatography (SE-HPLC) of $10 \mathrm{mg} \mathrm{mL}^{-1} \mathrm{HSA}$ solution at $\mathrm{pH} 7.4$.

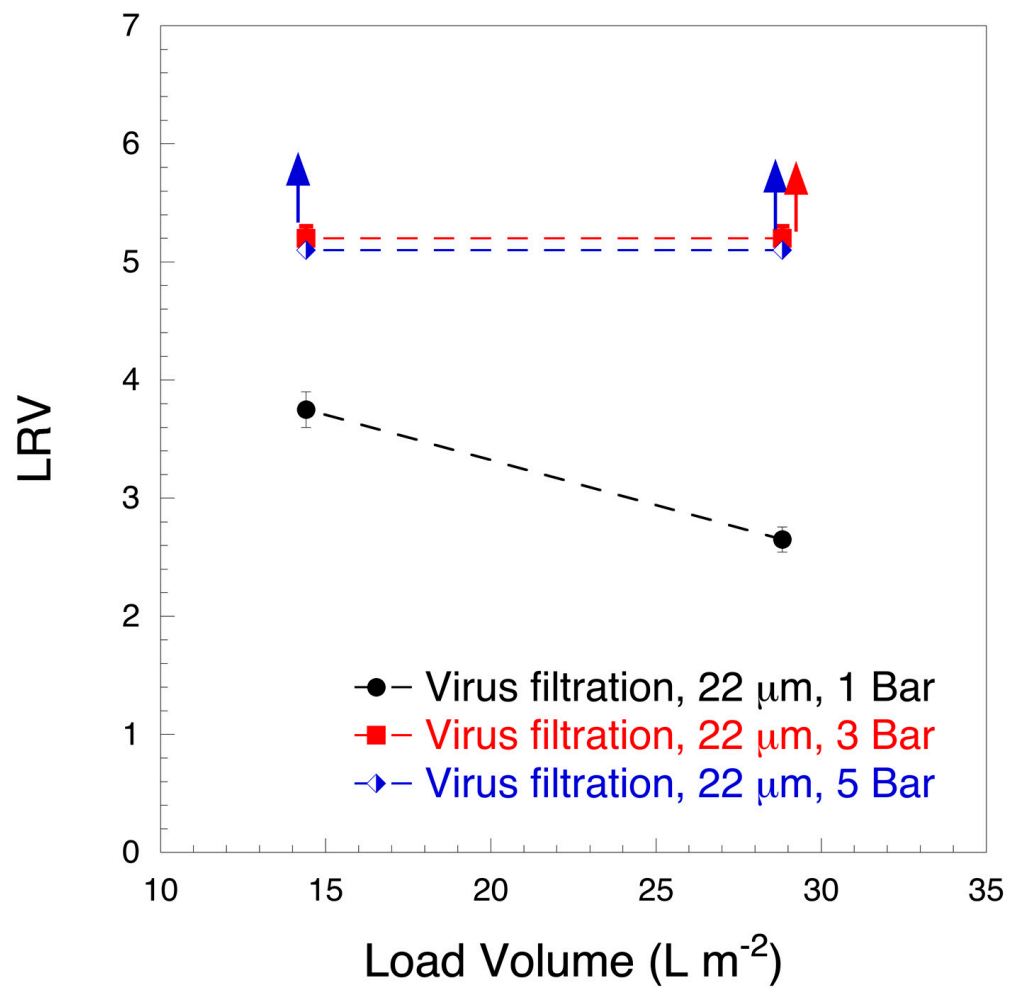

Figure 6. $\log _{10}$ reduction value (LRV) vs. load volume $\left(\mathrm{L} \mathrm{m}^{-2}\right)$ of $10 \mathrm{mg} \mathrm{mL}^{-1} \mathrm{HSA}$ spiked with ФX174 (28 nm) bacteriophage at pH 7.4. $(\mathrm{n}=3)$. Red and blue arrows correspond to 3 and 5 bar experiments, respectively, and indicate that no plaque forming units were detectable in the agar plate for the permeate fraction. 


\section{Conclusions}

The removal of HSA aggregates dramatically improved the flow properties of the filter, enabling high protein throughput and virus clearance. A distribution of pore sizes between $40 \mathrm{~nm}$ and $60 \mathrm{~nm}$, present in the $11 \mu \mathrm{m}$ prefilter and absent in the $22 \mu \mathrm{m}$ virus filter, played a crucial part in removing HSA aggregates. With respect to virus filtration, 1 bar constant pressure filtration showed poor removal ability of $\Phi \times 174$ bacteriophage ( $28 \mathrm{~nm}$ ), i.e., LRV $\leq 3.75$, while constant pressure filtration at 3 bar and 5 bar achieved LRV $>5$ and overall fast filtration. It is possible to more safely and quickly eliminate virus risk of plasma products while maintaining the biological activity of its various components.

Supplementary Materials: The following are available online at http://www.mdpi.com/2227-9059/8/7/209/s1, Figure S1: SEC-ÄKTA chromatography of $10 \mathrm{mg} \mathrm{mL}^{-1} \mathrm{HSA}$ solution at $\mathrm{pH}$ 7.4. SEC-ÄKTA chromatography. Protein Purification of HSA-PBS solution using Size Exclusion Chromatography (ÄKTA START) instrument. Selected chromatographic column (Mw 40-20,000 kDa; HiPrep 26/60 Sephacryl S-500HR, GE, Uppsala, Sweden) was used with a flow velocity of $1 \mathrm{~mL} \mathrm{~min}^{-1}$. The column was equilibrated with $0.5 \mathrm{cV}$ of PBS buffer and then 3.2 mL 1 wt. \% HSA-PBS solution was passed through the column using $3 \mathrm{cV}$. The purified solution was collected using peak fractionating in $10 \mathrm{~mL}$ falcon tubes, fractions were collected when absorbance was $\geq 5 \mathrm{mAU}$.

Author Contributions: Conceptualization, A.M. (Albert Mihranyan); methodology, A.M. (Albert Mihranyan); investigation, L.W., S.G., L.M., A.M. (Athanasios Mantas); resources, A.M. (Albert Mihranyan); data curation, L.W., S.G., A.M. (Athanasios Mantas), L.M., A.M. (Albert Mihranyan); writing-original draft preparation, L.W. and A.M. (Albert Mihranyan); writing—review and editing, A.M. (Albert Mihranyan); visualization, L.W.; supervision, A.M. (Albert Mihranyan); project administration, A.M. (Albert Mihranyan); funding acquisition, A.M. (Albert Mihranyan). All authors have read and agreed to the published version of the manuscript.

Funding: The project was funded by Knut and Alice Wallenberg Foundation (Bridge grant 2018.01141), Swedish Research Council [Vetenskapsrådet No. 2016-05715].

Conflicts of Interest: Corresponding author (AMi) is the inventor behind the nanocellulose-based virus removal filter paper.

$\begin{array}{ll}\text { Abbreviations } & \\ \text { BSA } & \text { bovine serum albumin } \\ \text { CHO } & \text { Chinese hamster ovary cells } \\ \text { CPV } & \text { canine parvovirus } \\ \text { DLS } & \text { dynamic light scattering } \\ \text { DMEM } & \text { Dulbecco's modified Eagle's medium } \\ \text { HSA } & \text { human serum albumin } \\ \text { ITS } & \text { insulin-transferrin-selenium } \\ \text { IVIG } & \text { intravenous immunoglobulin } \\ \text { LBM } & \text { Luria-Bertani medium } \\ \text { LRV } & \text { log10 reduction value } \\ \text { MVM } & \text { minute virus of mice } \\ \text { PFU } & \text { plaque forming units } \\ \text { PBS } & \text { phosphate buffer saline } \\ \text { SE-HPLC } & \text { size-exclusion high performance liquid chromatography } \\ \text { SEM } & \text { scanning electron microscopy } \\ \text { xMuLV } & \text { xenotropic murine leukemia virus }\end{array}$

\section{References}

1. Doweiko, J.P.; Nompleggi, D.J. Reviews: Role of Albumin in Human Physiology and Pathophysiology. J. Parenter. Enter. Nutr. 1991, 15, 207-211. [CrossRef] [PubMed]

2. Elsadek, B.; Kratz, F. Impact of albumin on drug delivery-New applications on the horizon. J. Control. Release 2012, 157, 4-28. [CrossRef] [PubMed]

3. Wang, J.; Ueno, H.; Masuko, T.; Hashimoto, Y. Binding of Serum Albumin on Tumor Cells and Characterization of the Albumin Binding Protein. J. Biochem. 1994, 115, 898-903. [CrossRef] [PubMed] 
4. De Castro, M.; Orive, G.; Gascón, A.; Hernandez, R.; Pedraz, J. Evaluation of human serum albumin as a substitute of foetal bovine serum for cell culture. Int. J. Pharm. 2006, 310, 8-14. [CrossRef] [PubMed]

5. Hreinsson, J.; Zhang, P.; Swahn, M.L.; Hultenby, K.; Hovatta, O. Cryopreservation of follicles in human ovarian cortical tissue. Comparison of serum and human serum albumin in the cryoprotectant solutions. Hum. Reprod. 2003, 18, 2420-2428. [CrossRef]

6. Goyen, M. Gadofosveset-enhanced magnetic resonance angiography. Vasc. Health Risk Manag. $2008,4,1$. [CrossRef]

7. Kobayashi, K. Summary of recombinant human serum albumin development. Biologicals 2006, 34, 55-59. [CrossRef]

8. He, Y.; Ning, T.; Xie, T.; Qiu, Q.; Zhang, L.; Sun, Y.; Jiang, D.; Fu, K.; Yin, F.; Zhang, W. Large-scale production of functional human serum albumin from transgenic rice seeds. Proc. Natl. Acad. Sci. USA 2011, 108, 19078-19083. [CrossRef]

9. Anraku, M.; Tsurusaki, Y.; Watanabe,H.; Maruyama, T.; Kragh-Hansen, U.; Otagiri, M. Stabilizing mechanisms in commercial albumin preparations: Octanoate and N-acetyl-l-tryptophanate protect human serum albumin against heat and oxidative stress. Biochim. et Biophys. Acta (BBA)-Proteins Proteom. 2004, 1702, 9-17. [CrossRef]

10. Anraku, M.; Kouno, Y.; Kai, T.; Tsurusaki, Y.; Yamasaki, K.; Otagiri, M. The role of N-acetyl-methioninate as a new stabilizer for albumin products. Int. J. Pharm. 2007, 329, 19-24. [CrossRef]

11. Kouno, Y.; Anraku, M.; Yamasaki, K.; Okayama, Y.; Iohara, D.; Nakamura, H.; Maruyama, T.; Hirayama, F.; Kragh-Hansen, U.; Otagiri, M. N-acetyl-L-methionine is a superior protectant of human serum albumin against post-translational oxidation as compared to N-acetyl-L-tryptophan. Biochem. Biophys. Rep. 2016, 6, 266-274. [CrossRef]

12. Erstad, B.L. Viral infectivity of albumin and plasma protein fraction. Pharmacother. J. Hum. Pharmacol. Drug Ther. 1996, 16, 996-1001.

13. Blümel, J.; Nhan, D.M.T.-X.; Teitz, S.; Miyabayashi, T.; Boller, K.; Schnierle, B.S.; Baylis, S.A. Inactivation and removal of Zika virus during manufacture of plasma-derived medicinal products. Transfusion 2016, 57, 790-796. [CrossRef]

14. Farcet, M.R.; Kreil, T.R. Zika virus is not thermostable: Very effective virus inactivation during heat treatment (pasteurization) of human serum albumin. Transfusion 2016, 57, 797-801. [CrossRef] [PubMed]

15. Kühnel, D.; Müller, S.; Pichotta, A.; Radomski, K.U.; Volk, A.; Schmidt, T. Inactivation of Zika virus by solvent/detergent treatment of human plasma and other plasma-derived products and pasteurization of human serum albumin. Transfusion 2016, 57, 802-810. [CrossRef] [PubMed]

16. Leydold, S.M.; Farcet, M.R.; Kindermann, J.; Modrof, J.; Pölsler, G.; Berting, A.; Howard, M.K.; Barrett, P.N.; Kreil, T.R. Chikungunya virus and the safety of plasma products. Transfusion 2012, 52, 2122-2130. [CrossRef] [PubMed]

17. Yue, C.; Teitz, S.; Miyabashi, T.; Boller, K.; Lewis-Ximenez, L.L.; Baylis, S.A.; Blümel, J. Inactivation and Removal of Chikungunya Virus and Mayaro Virus from Plasma-derived Medicinal Products. Viruses 2019, 11, 234. [CrossRef]

18. Blümel, J.; Rinckel, L.A.; Lee, D.C.; Roth, N.J.; Baylis, S.A. Inactivation and neutralization of parvovirus B19 Genotype 3. Transfusion 2012, 52, 1490-1497. [CrossRef]

19. Blümel, J.; Schmidt, I.; Willkommen, H.; Löwer, J. Inactivation of parvovirus B19 during pasteurization of human serum albumin. Transfusion 2002, 42, 1011-1018. [CrossRef]

20. Farcet, M.R.; Kindermann, J.; Modrof, J.; Kreil, T.R. Inactivation of hepatitis A variants during heat treatment (pasteurization) of human serum albumin. Transfusion 2011, 52, 181-187. [CrossRef]

21. Gröner, A.; Broumis, C.; Fang, R.; Nowak, T.; Popp, B.; Schäfer, W.; Roth, N.J. Effective inactivation of a wide range of viruses by pasteurization. Transfusion 2017, 58, 41-51. [CrossRef] [PubMed]

22. Klammt, S.; Brinkmann, B.; Mitzner, S.; Munzert, E.; Loock, J.; Stange, J.; Emmrich, J.; Liebe, S. Albumin Binding Capacity $(\mathrm{ABiC})$ is reduced in commercially available Human Serum Albumin preparations with stabilizers. Zeitschrift für Gastroenterologie 2001, 39, 24-27. [CrossRef] [PubMed]

23. Harm, S.; Schildböck, C.; Hartmann, J. Removal of stabilizers from human serum albumin by adsorbents and dialysis used in blood purification. PLoS ONE 2018, 13, e0191741. [CrossRef] [PubMed]

24. Bar-Or, D.; Bar-Or, R.; Rael, L.; Gardner, D.K.; Slone, D.S.; Craun, M.L. Heterogeneity and oxidation status of commercial human albumin preparations in clinical use. Crit. Care Med. 2005, 33, 1638-1641. [CrossRef] 
25. Stange, J. Extracorporeal liver support. Organog 2011, 7, 64-73. [CrossRef] [PubMed]

26. Wong, W.-W.; MacKenzie, A.D.; Nelson, V.J.; Faed, J.M.; Turner, P.R. Octanoate in Human Albumin Preparations Is Detrimental to Mesenchymal Stromal Cell Culture. Stem Cells Int. 2015, 2015, 192576. [CrossRef]

27. Lang, B.E.; Cole, K.D. Unfolding properties of recombinant human serum albumin products are due to bioprocessing steps. Biotechnol. Prog. 2014, 31, 62-69. [CrossRef]

28. Dengler, T.; Stöcker, U.; Kellner, S.; Fürst, G. Chemical and Immunochemical Characterization of Polymers or Aggregates in Preparations of Human Serum Albumin. Transfus. Med. Hemother. 1989, 16, 160-164. [CrossRef]

29. Jensen, L.B.; Dam, J.; Teisner, B. Identification and Removal of Polymer- and Aggregate-Forming Proteins in Human Plasma Albumin Preparations. Vox Sang. 1994, 67, 125-131. [CrossRef]

30. Gay, M.; Carrascal, M.; Gorga, M.; Parés, A.; Abian, J. Characterization of peptides and proteins in commercial HSA solutions. Proteomics 2010, 10, 172-181. [CrossRef]

31. Lin, J.-J.; Meyer, J.D.; Carpenter, J.F.; Manning, M.C. Stability of human serum albumin during bioprocessing: Denaturation and aggregation during processing of albumin paste. Pharm. Res. 2000, 17, 391-396. [CrossRef]

32. Lin, J.-J.; Meyer, J.D.; Carpenter, J.F.; Manning, M.C. Aggregation of human serum albumin during a thermal viral inactivation step. Int. J. Boil. Macromol. 2009, 45, 91-96. [CrossRef] [PubMed]

33. Maruyama, T.; Katoh, S.; Nakajima, M.; Nabetani, H. Mechanism of bovine serum albumin aggregation during ultrafiltration. Biotechnol. Bioeng. 2001, 75, 233-238. [CrossRef] [PubMed]

34. Metreveli, G.; Wågberg, L.; Emmoth, E.; Belák, S.; Strømme, M.; Mihranyan, A. A Size-Exclusion Nanocellulose Filter Paper for Virus Removal. Adv. Healthc. Mater. 2014, 3, 1546-1550. [CrossRef] [PubMed]

35. Asper, M.; Hanrieder, T.; Quellmalz, A.; Mihranyan, A. Removal of xenotropic murine leukemia virus by nanocellulose based filter paper. Biologicals 2015, 43, 452-456. [CrossRef]

36. Gustafsson, S.; Lordat, P.; Hanrieder, T.; Asper, M.; Schaefer, O.; Mihranyan, A. Mille-feuille paper: A novel type of filter architecture for advanced virus separation applications. Mater. Horizons 2016, 3, 320-327. [CrossRef]

37. Gustafsson, S.; Mihranyan, A. Strategies for Tailoring the Pore-Size Distribution of Virus Retention Filter Papers. ACS Appl. Mater. Interfaces 2016, 8, 13759-13767. [CrossRef]

38. Manukyan, L.; Li, P.; Gustafsson, S.; Mihranyan, A. Growth media filtration using nanocellulose-based virus removal filter for upstream biopharmaceutical processing. J. Membr. Sci. 2019, 572, 464-474. [CrossRef]

39. Manukyan, L.; Padova, J.; Mihranyan, A. Virus removal filtration of chemically defined Chinese Hamster Ovary cells medium with nanocellulose-based size exclusion filter. Biologicals 2019, 59, 62-67. [CrossRef]

40. Wu, L.; Manukyan, L.; Mantas, A.; Mihranyan, A. Nanocellulose-Based Nanoporous Filter Paper for Virus Removal Filtration of Human Intravenous Immunoglobulin. ACS Appl. Nano Mater. 2019, 2, 6352-6359. [CrossRef]

41. Manukyan, L.; Mantas, A.; Razumikhin, M.; Katalevsky, A.; Golubev, E.; Mihranyan, A. Two-Step Size-Exclusion Nanofiltration of Prothrombin Complex Concentrate Using Nanocellulose-Based Filter Paper. Biomedicines 2020, 8, 69. [CrossRef] [PubMed]

42. Badmington, F.; Wilkins, R.; Payne, M.; Honig, E.S. Vmax testing for practical microfiltration train scale-up in biopharmaceutical processing. Pharm. Technol. 1995, 19, 64-76.

43. Barrett, E.P.; Joyner, L.G.; Halenda, P.P. The determination of pore volume and area distributions in porous substances. I. Computations from nitrogen isotherms. J. Am. Chem. Soc. 1951, 73, 373-380. [CrossRef]

44. Sing, K.S.; Williams, R.T. Physisorption Hysteresis Loops and the Characterization of Nanoporous Materials. Adsorpt. Sci. Technol. 2004, 22, 773-782. [CrossRef]

45. Gustafsson, S.; Westermann, F.; Hanrieder, T.; Jung, L.; Ruppach, H.; Mihranyan, A. Comparative Analysis of Dry and Wet Porometry Methods for Characterization of Regular and Cross-Linked Virus Removal Filter Papers. Membranes 2018, 9, 1. [CrossRef]

46. Gustafsson, O.; Gustafsson, S.; Manukyan, L.; Mihranyan, A. Significance of Brownian Motion for Nanoparticle and Virus Capture in Nanocellulose-Based Filter Paper. Membranes 2018, 8, 90. [CrossRef]

(C) 2020 by the authors. Licensee MDPI, Basel, Switzerland. This article is an open access article distributed under the terms and conditions of the Creative Commons Attribution (CC BY) license (http://creativecommons.org/licenses/by/4.0/). 